University of Wollongong

Research Online

Faculty of Business - Papers (Archive)

Faculty of Business and Law

$1-1-2011$

Taxes, international clienteles and the value of ADR dividends

Aelee Jun

University of Wollongong, ajun@uow.edu.au

Graham H. Partington

University of Sydney

Follow this and additional works at: https://ro.uow.edu.au/buspapers

Part of the Business Commons

Research Online is the open access institutional repository for the University of Wollongong. For further information contact the UOW Library: research-pubs@uow.edu.au 


\title{
Taxes, international clienteles and the value of ADR dividends
}

\author{
Abstract \\ The values of ADR dividends are estimated from the period when, due to different ex-dividend dates, the \\ ADRs and their underlying Australian stocks trade with differential dividend entitlements. These estimates \\ of ADR dividend values are significantly less noisy than traditional exdividend estimates. The ADR \\ dividends are valued at less than their face value and the dividends on the stocks at more than their face \\ value. This is consistent with the ADRs being held by U.S. investors placing little value on the imputation \\ tax credits attached to the dividends and the converse for Australian resident investors.

\section{Keywords} \\ adr, value, clienteles, taxes, international, dividends \\ Disciplines \\ Business

\section{Publication Details} \\ A. Jun \& G. Partington (2011). Taxes, international clienteles and the value of ADR dividends. 9th INFINITI \\ Conference on International Finance 2011- "Institutions, Actors and International Finance", 13-14 Jun \\ 2011.
}


Keywords: Risk management, Corporate governance, Financial performance, Financial crisis, Bank holding companies

Takeover Prediction Using Forecast Combinations Bruno Dore Rodrigues, The University of Sydney, Australia *Maxwell Stevenson, The University of Sydney, Australia

Discussant: William Simpson, Oklahoma State University, USA

The ability to identify likely takeover targets at an early stage could provide an investor with valuable information to profit from investing in potential target firms. In this paper we contribute to the takeover forecasting literature by suggesting the combination of probability forecasts as an alternative method to improve forecast accuracy in takeover prediction and to, therefore, realize improved economic return in portfolios made up from predicted targets. Forecasts from several nonlinear forecasting models, such as logistic and neural network models and combinations of them, are used to explore the methodology that better reduces the out-of-sample misclassification error. We draw two general conclusions from our results. First, the combination methods outperform the single models and should be used to improve the prediction accuracy of takeover targets. Second, we demonstrate that an investment in portfolios of the combined predicted targets results in significant abnormal returns being made by an investor in the order of up to four times the market benchmark return, and in a portfolio of manageable size.

Keywords: takeover prediction, forecast combination, accuracy, economic value

\section{Session 6c, Swift: Cross Listings}

Chair: Graham Partington, The University of Sydney, Australia

What Makes the Bonding Stick? A Natural Experiment Involving the Supreme Court and Cross-Listed Firms

*Amir Licht, IDC Interdisciplinary Center Herzliya, Israel

Xi Li, Boston College, USA

Jordan Siegel, Harvard University, USA

Discussant: Graham Partington, The University of Sydney, Australia

Using a natural experiment to overcome the empirical challenges facing the debate over the bonding hypothesis, we analyze markets' reaction to a sudden radical change in the world of U.S.-listed foreign firms. In March 2010, the U.S. Supreme Court signalled its intention to geographically limit the reach of the U.S. antifraud regime. The Court thus excluded the overwhelming majority of investors in U.S.-listed foreign firms from the protection of the U.S. civil liability regime and cast at least partial limitations on the SEC's regulatory authority. This event nonetheless was met with positive abnormal returns of U.S.-listed foreign firms all over the world. These abnormal returns are actually higher the greater the percentage of a firm's capital listed on non-U.S.-exchanges. We find no evidence that markets' reaction to this event related to the corporate governance and legal environment in foreign issuers' home country. These results challenge the legal bonding hypothesis while suggesting that the U.S. regime of civil liability as currently designed may not have been seen as a source of economic value for outside investors.

Keywords: cross-listing, corporate governance, civil liability, bonding

Cross-listing Across European Markets and Accruals Management *Stuart McLeay, The University of Sydney, Australia

Christina Dargenidou, University of Exeter, UK

Aziz Jaafar, Bangor University, UK

Discussant: Amir Licht, IDC Interdisciplinary Center Herzliya, Israel

The present study investigates whether there is a significant association between the cross-listing decision in European markets and the exercise of managerial discretion in financial reporting in terms of discretionary working capital accruals. The empirical evidence establishes that crosslisting across European markets has a significant effect on earnings management, with firms becoming subject to significantly different circumstances in terms of scrutiny by analysts and investors, compared with those firms that are listed only in their own jurisdiction.
Taxes international clienteles and the value of ADR dividends Jun Aelee, University of Wollongong, Australia *Graham Partington, The University of Sydney, Australia Discussant: Aziz Jaafar, Bangor University, UK

The values of ADR dividends are estimated from the period when, due to different ex-dividend dates, the ADRs and their underlying Australian stocks trade with differential dividend entitlements. These estimates of ADR dividend values are significantly less noisy than traditional exdividend estimates. The ADR dividends are valued at less than their face value and the dividends on the stocks at more than their face value. This is consistent with the ADRs being held by U.S. investors placing little value on the imputation tax credits attached to the dividends and the converse for Australian resident investors.

Keywords: Dividends, ADR, clienteles, imputation, taxes.

\section{Session 6d, Ui Chadhain: Real Estate} Chair: Gunter Löffler, Universität Ulm, Germany

\section{Housing And The Macroeconomy}

*Ambrogio Cesa-Bianchi, Università Cattolica del Sacro Cuore, Italy Alessandro Rebucci, Inter-American Development Bank, USA Discussant: Peter N Posch, Universität Ulm, Germany

The recent financial crisis and the ensuing global recession and slow recovery showed how movements in the housing market can be important impulses to business fluctuations and corroborated the crucial role played by developing countries in the world economy. This paper investigates (1) to what extent housing cycles are country specific or driven by global factors and (2) the effects of housing shocks on real output. Empirical evidence based on dynamic correlations and factor analysis shows that a significant portion of the variation in house price inflation can be explained by global and regional factors. Motivated by these results, I estimate a Global VAR model -which implicitly takes into account unobserved global factors- augmented with house prices, with quarterly data from 1979(1) to 2009(4) for all major advanced (AEs) and emerging economies (EMs) of the world. In AEs, the global impulse response functions to negative US and global housing shocks are associated with a large drop of output, the impact of the latter being larger and more long-lasting than the former. The drop in economic activity is somewhat similar to the one observed during the global crisis. Among EMs, responses are heterogeneous. In particular, the impulse responses show that BRICs are not affected by neither US nor global housing shocks, supporting the view that nowadays, "when the US sneezes, not everyone gets cold".

Keywords: Global housing cycle, GVAR, Conditional factor analysis

Hedge Funds and the US Real Estate Bubble: Evidence from NYSE Real Estate Companies

*Theodoros Stamatiou, University of Piraeus, Greece

Gikas Hardouvelis, University of Piraeus, Greece

Discussant: Ambrogio Cesa-Bianchi, Università Cattolica del Sacro Cuore, Italy

The recent US Real Estate Bubble had consequences not only for the rea economy but for the stock market as well. Real Estate Investment Trusts' (REITs) prices reached levels which could not be supported by their fundamentals until mid-2007. Using this observation as a starting point we assume that hedge fund managers are rational investors and we examine their holdings behavior in the REITs sector of the NYSE. Our working assumption is based on the DeLong et al [11] and Abreu \& Brunnermeier [1] argument that rational investors under certain conditions may not always short a bubble but instead ride it so as to gain from the price rise. Using data on hedge fund managers holdings from the $13 \mathrm{f}$ filing database provided by Thomson Financial we find that hedge funds were overloaded with REITs stocks prior to the price peak of the sector but their positions were placed in such a way that they gained from this strategy. Moreover, non-specialized hedge fund managers outperformed specialized ones.

Keywords: Hedge Funds, 13 filing, Rational Investors, Bubble, Real Estate, REITS 